\section{THE RELATIONSHIP BETWEEN DEPOSITS WITH BANKS AND BANKS' LOANS DEPENDS ON THE SIZE OF THE BANK (CASE STUDY OF SERBIA)}

\section{INTRODUCTION}

Deposits are a bank's financial liability to those who give their money to the bank and, at the same time, the basic, cheapest, and the highest quality source of funding available on the financial markets. "Deposits are the foundation upon which banks thrive and grow. They have a unique position in a bank's balance sheet that differentiates it from other legal entities. Deposits provide most of the raw materials for bank loans and thus represent the ultimate source of bank profits and growth" (4). Deposits also play a pivotal role in a bank's funding, as a predominant portion of commercial bank's assets is usually financed through customer deposits $(2,14)$. Among other things, commercial banks collect deposits, through the network of their branches and agencies, and this activity, known as fund mobilization, is considered an 'input' activity of the bank (1, 175-212).

An increase in deposits increases a bank's financial and credit potential. The management of a bank's business policy is directly dependent on the deposit level, structure, and maturity.

The most important and the most common bank investments are investments in loans, as banks generate the highest income from these investments. Most research shows that banks generate two-thirds of their revenue from corporate and retail lending ${ }^{2}$. Experience shows that European banks mainly invest in loans, as opposed to US banks, where banks' investments are much more diversified, especially investments in se-

\section{SUMMARY}

Key words: Bank deposits and loans, small, medium and large banks, Serbia.

Deposits are the cheapest funds obtained by a bank which are mostly invested in loans. The objective of the paper is to identify if there is any difference in correlation between deposits and loans among commercial banks of different sizes. This paper contributes to the existing banking literature by exploring the strictly regulated banking industry and is one of the few to investigate the correlation between deposits and investments in commercial banking in general.

\footnotetext{
' Radomir Šalić,Vanredni profesor, University Metropolitan, Faculty of Management, Beograd. radomir.salic@metropolitan.ac.rs 2 https://www.nbs.rs/internet/cirilica/50/50_5.html:This site shows the achieved results in the Income statement as of $30 / 06 / 2019$ where, for example, the share of interest income from investment in loans is: in Banca Intesa 69.4\%, in Komercijalna banka $66.8 \%$, etc.
} 
curities. When it comes to domestic experience, the banks' investment policy is based on retail and corporate lending. If the bank wants to achieve short-term goals, it favors retail investments.

This research aims to determine if there is a difference in the level of correlation of deposits and investments in loans between commercial banks of different sizes. The scope of the research includes commercial banks in Serbia.

\section{METHODOLOGY AND DATA}

Serbia's banking system comprised 26 commercial banks $(3,2)$ on June 30, 2019, with assets of 3,800 billion dinars (EUR 32 billion). There are huge differences in the size of their assets ranging from 6,000 million dinars (approximately EUR 50 million) to 600,000 million dinars (roughly EUR 5 billion). For the purpose of the research, banks are classified into three groups: small, medium, and large banks.

Small banks comprise 13 banks with assets worth 6,000 million to 100,000 million dinars (EUR 50 to 850 million). These banks make up $50 \%$ of all banks in Serbia, and their total asset value amounts to 397,000 million dinars (EUR 3.3 billion), which is only $10.43 \%$ of the total assets of all banks. Medium-sized banks, 9 of them, make up 34.6\% of the total number of banks, with assets value of $43.32 \%$ or 1,600 billion dinars (slightly less than EUR 14 billion). four large banks account for only $15.4 \%$ of banks or, but with the most significant asset value accounting for $46.25 \%$ of total assets or 1,760,000 million dinars (slightly less than EUR 15 billion) in relative values.

We studied the correlation or dependencies between deposits " $\mathrm{x}$ " (independent variable) and investments in loans " $\mathrm{y}$ " (dependent variable). We will determine the relationship between deposits and loans cumulatively for all banks and by groups of banks, small, medium, and large, based on their asset values stated in balance sheets as of June 30,2019. The statistical calculation (coefficient of correlation, regression lines, and coefficient of determination) was performed in Excel.

\section{RESULTS AND DISCUSSION}

The total value of 26 banks' assets, as of June 30, 2019, amounted to 3,809,980 million dinars, or approximately EUR 32.2 billion. The total value of all deposits amounted to 3,020,409 million dinars (approximately EUR 25.6 billion), and the total value of all loans amounted to 2,425,581 million dinars (approximately EUR 20.5 billion). 
The value of deposits and loans is always lower than total assets since no commercial bank invests solely in loans, but also invests in other forms of assets, such as securities, liquidity reserves with the central bank, etc.

Table 1: The structure of the commercial banking system in Serbia

\begin{tabular}{lcccccc}
\hline \multicolumn{1}{c}{ Group } & $\begin{array}{c}\text { Number } \\
\text { of banks }\end{array}$ & Share in \% & $\begin{array}{c}\text { Asset value in } \\
\text { DINARS million }\end{array}$ & $\begin{array}{c}\text { Share of asset } \\
\text { value in \% }\end{array}$ & $\begin{array}{c}\text { Deposits in } \\
\text { DINARS million }\end{array}$ & $\begin{array}{c}\text { Loans in } \\
\text { DINARS million }\end{array}$ \\
\hline Small banks & 13 & $50.0 \%$ & 397,458 & $10.43 \%$ & 301,434 & 271.345 \\
\hline Medium banks & 9 & $34.6 \%$ & $1,650,475$ & $43.32 \%$ & $1,312,759$ & $1,048,037$ \\
\hline Large banks & 4 & $15.4 \%$ & $1,762,046$ & $46.25 \%$ & $1,406,216$ & $1,106,198$ \\
\hline Total & $\mathbf{2 6}$ & $\mathbf{1 0 0 . 0 \%}$ & $\mathbf{3 , 8 0 9 , 9 8 0}$ & $\mathbf{1 0 0 . 0 0 \%}$ & $\mathbf{3 , 0 2 0 , 4 0 9}$ & $\mathbf{2 , 4 2 5 , 5 8 1}$ \\
\hline
\end{tabular}

The first step was to research the general relationships between deposits and loans for all 26 banks. The correlation coefficient between deposits and loans for all 26 banks of 0.9737 shows a robust positive linear correlation between deposits and loans, as presented in Chart 1.

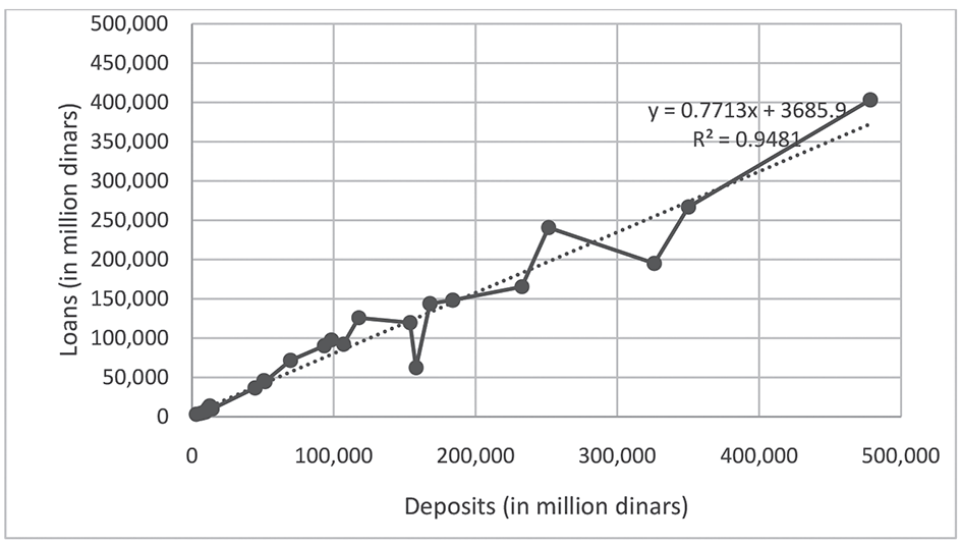

Chart 1: Total deposits and loans of all banks in Serbia scatterplot as of June 30, 2019

The equation of the linear regression model is:

$$
y=0.7713 x+3.686
$$

where $x$ denotes deposits, and y denotes loans. It is assumed that in the equation $x=0$, the value of loans should be: $y=3.686$ million dinars. Even if there are no deposits, there would be some loans, as a bank, apart from deposits, has capital and borrowings that could be partly invested in loans.

With the increase of variable $x$ by one million dinars, projected investments in loans would increase by 0.7713 million dinars. The coefficient of determination equals 0.9481 . 
Classification of banks into three groups, small $\left(r_{1}\right)$, medium $\left(r_{2}\right)$, and large banks $\left(r_{3}\right)$, make the calculation of relevant correlation coefficients by groups possible.

The relationship between deposits and loans of small banks is described by the coefficient of correlation of $y=0.968$ and the coefficient of determination by $\mathrm{R}^{2}=0.9481$.

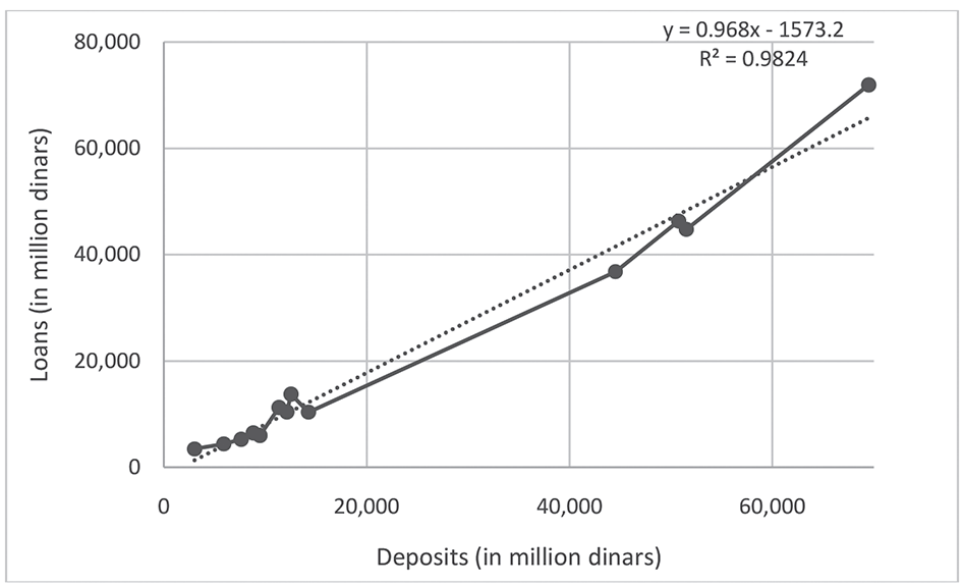

Chart 2: Aggregated values of deposits and loans of the small banks

The equation of the linear regression model for the group of small banks is:

$$
\mathrm{y}=0.968 \mathrm{x}-1.573
$$

The increase in the value of variable $x$, i.e., deposits, by 1 million dinars, would increase small banks' loans by 0.986 million dinars. The coefficient of determination $R_{1}^{2}$ is also very high and equals 0.984 . The correlation coefficient of 0.991 shows a robust linear positive correlation between variables $\mathrm{x}$ and $\mathrm{y}$, revealing that small bank investments in loans are highly dependent on deposits. The correlation coefficient of small banks is higher than the coefficient of all banks, as:

$$
0.991>0.973
$$

The lowest deposit of small banks in our example is 3.028 million dinars, and the highest is 69.507 million dinars. If one small bank invested or collected 100,000 million dinars of deposits, then, according to this linear regression model, investment of funds could be expected to amount to as high as $96.798,43$ million dinars, i.e.:

$$
\mathrm{y}=0.968 \times 100.000-1.573=96,798.43 \text { million dinars. }
$$

Therefore, small banks' utilization rate of deposits is very high. The correlation coefficient $R_{1}^{2}$ or the reliability coefficient for small banks equals 0.9824 , which means that the model is very reliable. 
Medium-sized banks include banks with assets in the range of approximately EUR 800 million to EUR 2.5 billion.

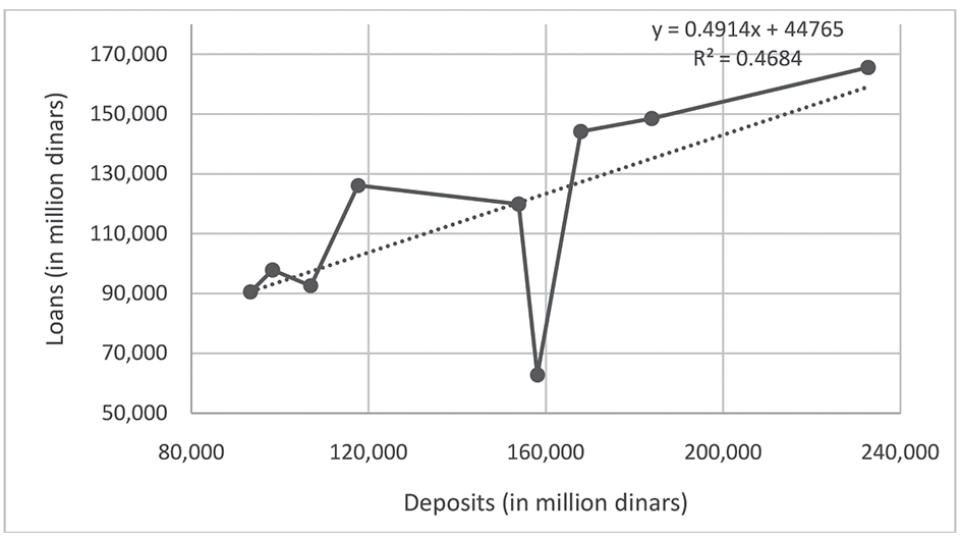

Chart 3: Aggregated values of deposits and loans of the medium size banks

The regression function of medium-sized banks in Serbia is also linear and positive and is presented as:

$$
\mathrm{y}=0.4914 \mathrm{x}+44766
$$

Coefficients of determination is $\mathrm{R}_{2}^{2}=0.468$. This result shows that the correlation coefficient of variables $\mathrm{x}$ and $\mathrm{y}$ (deposits and investments) of medium-sized banks is much lower than that of small banks and is in the range of moderate correlations. The reliability of the medium-sized bank model $\left(\mathrm{R}_{2}{ }^{2}\right)$ is lower than that of small banks, as well as the coefficient of determination of all banks.

Large banks include banks whose assets are in the range of over 251,509 million dinars or over EUR 2 billion. There are four large banks in Serbia, and they cover the most significant part of deposits and loans.

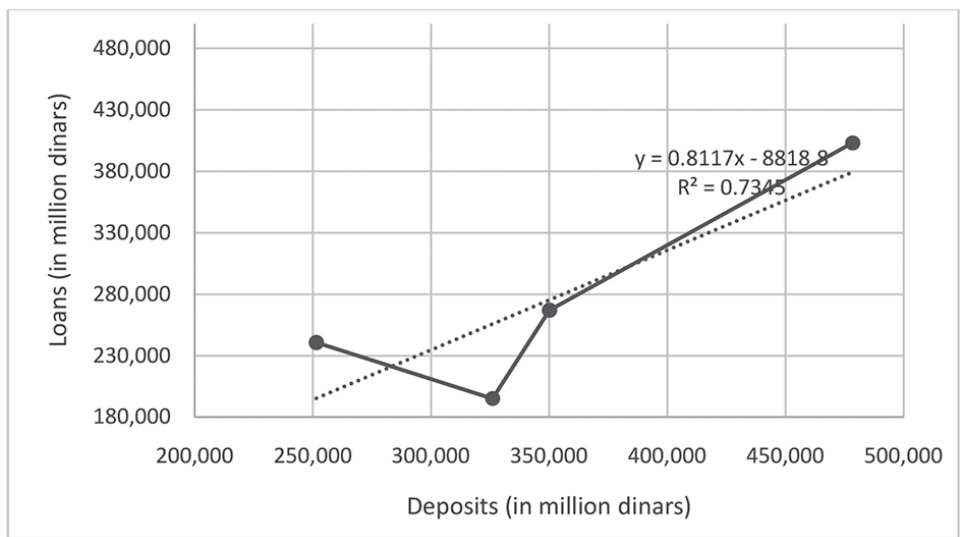

Chart 4: Aggregated values of deposits and loans of the large banks

The regression function of large banks in Serbia is also linear and positive and is presented as: 
ODNOS IZMEDU UZETIH DEPOZITA I DATIH KREDITA ZAVISI ODVELIČINE BANKE? REZIME

Ključne reči: Bankarski depoziti i krediti, male, srednje i velike banke, Srbija.

Depoziti su najjeftiniji izvor sredstava koje banke najvećim delom plasiraju u vidu kredita. Cilj ovog rada je da ispita da li ima razlike u korelaciji između visine depozita i datih kredita između komercijalnih banaka različite veličine. Ovaj rad dopunjuje postojeću literaturu o bankama, koja se bavi strogo regulisanom delatnošću banaka i jedan je od nekoliko istraživanja korelacije između depozita i plasmana kod komercijalnih banaka.

$$
y=0.8117 x-8.818
$$

The correlation coefficient of 0.8117 also shows a strong linear positive correlation between deposits $\mathrm{x}$ and loans $\mathrm{y}$.

Loan investments are highly dependent on the size of deposits, significantly more dependent than in medium-sized banks and less dependent than in small banks.

The research results show that investments of banks' funds in loans largely depend on the size of bank deposits. However, the level of dependence measured by the correlation coefficient differs among small, medium, and large banks' groups. The analysis shows that:

- small bank investments in loans depend mainly on the size of bank deposits,

- medium size bank investments in loans are less dependent on deposits than small and large banks.

Medium-sized banks behave more comfortably than large banks and, especially, small banks. They invest a significant portion of their deposits in securities (government bonds) they buy through repo and other financial transactions from the central bank, thus ensuring for themselves a secure but slightly lower income than the income they would generate from investments in loans.

\section{CONCLUSION}

The research confirmed the initial assumption that the size of commercial bank deposits significantly affect the size of bank investments in loans. This impact is the most significant in small banks. Besides loans, medium and large banks invest in securities, deposits with the central bank, and accounts with correspondent banks. Among diverse paths for future research, it would be interesting to investigate the relationship or level of interdependence between deposits and other investments such as investments in the capital and money markets. In addition, a more in-depth study of loan and deposit utilization efficiency should be done based on factors such as bank client behavior.

\section{LITERATURE}

1. Berger, A. N. 1997 Efficiency of financial institutions: International survey and directions for future research. European Journal of Operational Research, 98, 175-212.

2. Bologna, Pierluigi 2011 Is there a Role for Funding in Explaining Recent U.S. Banks' Failures?, IMF, WP No. 11/180, Washington.

3. National bank of Serbia (2019) Banking sector in Serbia Second Quarter Report 2019, Beograd.

4. Rose, P. S. 2003 Menadžment komercijalnih banaka, MATE, Zagreb. 